\title{
Current Directions and Future Research Priorities of Customer Data Analysis
}

\author{
Mohammed M Mohammed', Nagi A. Mohamed², Ali A. Adam³, Shazali S. \\ Ahmed $^{4}$, Fakhreldeen A. Saeed ${ }^{5}$ \\ 1,2Information Systems, Al-Neelain University - Sudan, Khartoum \\ ${ }^{3}$ Accounting Information Systems, Al-Neelain University - Sudan, Khartoum \\ 4nformation Technology, Al-Neelain University - Sudan, Khartoum \\ ${ }^{5}$ Software Engineering, Al-Neelain University - Sudan, Khartoum \\ Email: jnaabo.haj@gmail.com¹, anagii66@gmail.com², misterali88@gmail.com³ \\ shazali33@gmail.com ${ }^{4}$, fakhry00@gmail.com ${ }^{5}$
}

\begin{abstract}
Customer analysis is receiving special attention from both researchers and professionals. The objective of this paper is to identify the trends of techniques used to address customer's current problems and shed light on future research directions using a literature review. We reviewed the literature for the last five years. The findings revealed that customer purchase was the most popular technique used by the research community followed by customer satisfaction and visit wit. Whereas customer segmentation and customer churn were the least. However, the regression method was commonly used for predicting customer purchase and behavior. But social media and big data are still in their early stages for customer analytics research.
\end{abstract}

Keywords: Customer analysis, customer purchase, customer satisfaction, data analysis

\section{INTRODUCTION}

Recently, there has been an increase in attention to collect data and analyzed to discover useful knowledge in many different business domains. The availability and accessibility of customer transaction data were due to the increased improvements in the information technology domain. The meaningful information that is discovered is then used by the companies for customer relationship management (CRM). Providing accurate information is important for efficient resource management[1]. Decision-makers will benefit from decision support models that relate historical transactions to the future. The historical records are, therefore, transformed into competitive advantages, by using analytics tools and techniques[2]. 
Various researches have started to concentrate on understanding customer data. Customer analysis has received wide attention from both academia and practitioners[3]. The customer has become a centric point. Attracting and retaining high-quality customers is a priority for businesses in this competitive environment. Firms are developing and applying marketing techniques[4].

In this work literature review was used to identify the current and future directions about customer science, and the trends of techniques are used by research as well as professional communities. We discussed the main customer science areas of research. The rest of this paper is organized as follows the customer analytics in section 2, section 3 explains customer purchase trends, section 4 addresses future priorities for customer analytics, results in section 5 , conclusion in section 6 , and last future directions.

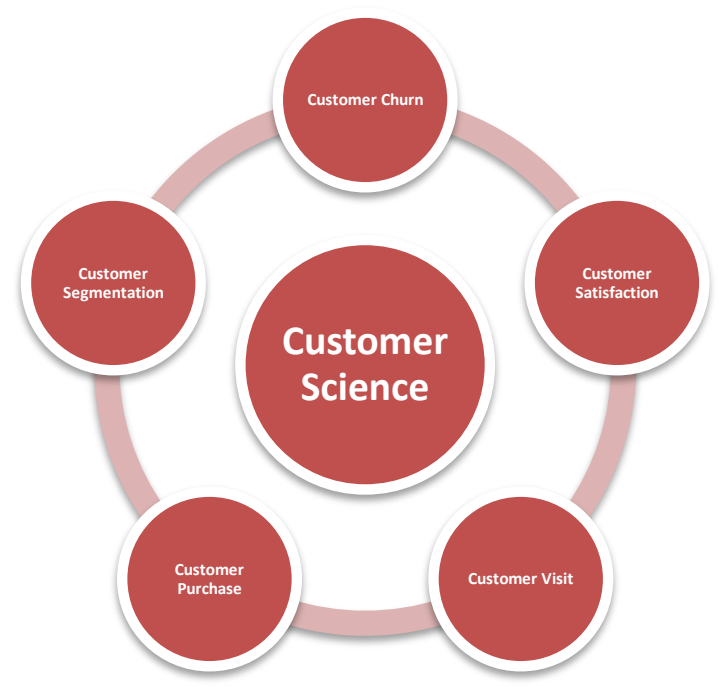

Fig. 1. Shows customer science techniques.

The figure above demonstrates the most popular five customer science fields of research are: customer purchase, customer satisfaction, customer visit, customer segmentation, and customer churn

\section{CUSTOMER ANALYTICS}

The following section is addressing customer analytics research areas are and their current and future trends customer churn, customer satisfaction, customer visit, customer purchase, and customer segmentation 


\subsection{Customer Churn}

Customer churn means the registered consumers who are increasingly turning to another company or institution due to the loss of satisfaction. Customer churn analysis is used to make effective decisions in business and improve products. Attracting a new customer is six times more expensive than keeping the current customer. Long-term customers are more profitable than new customers. More interestingly, a satisfied customer is a source of spreading good and positive image about the product and services [5]. Therefore, customer churn prediction is significant in the success of any business in a competitive environment.

\subsection{Satisfaction}

One of the vital competitive advantages in the coming years is to provide products and services with great customer satisfaction[6]. Consumers who are pleasant purchase more items, pay more, spend more time, and are more content[7]. Customers' purchase prediction is crucial for designing personalized services and in marketing, which provides contributions to businesses in the enhancement of customer loyalty and satisfaction[8].

\subsection{Customer Visit}

Most shoppers do not purchase from the first visit as [9] reported that only two percent purchase from the first visit, eight percent come back for purchase. Future research is needed to increase the window of shoppers from the first visit. First businesses should develop an understanding of the window-shopping patterns. Through which can identify their customers' needs. Predict customer visiting intention[3]. Studied the relationship between social media and visiting intention[10]. Customers visiting unpopular businesses are more likely to be driven by their personal preferences. However, Customers who visit popular businesses are mostly influenced by social media[11]. Social media has become a place where customers share their preferred products and services[12].

\subsection{Customer Purchase}

Customer purchasing analysis and prediction have gained extensive attention from both researchers and professionals, for understanding customer behavior ecommerce can deliver much and rich data about customer behaviors for future analyses. L. Tang et al. Observed that the machine learning models were 
powerful and significant compared to traditional statistical ones when it comes to prediction accuracy[13][14]. The customer analysis technique enables companies to communicate with the true customer, at the right time, by the expected offer[15]. Improving online purchase conversion rates by increasing the likelihood of a visiting customer to result in a purchase transaction[13]. Customer purchase is considered to be the main objective of online marketing research. The probability of the purchase could increase significantly by limiting the choices with personalized products[16].

\subsection{Customer Segmentation}

Customer segmentation enables businesses to target a specific set of customers also supports a strong durable relationship with the customers and helps for the efficient distribution of marketing resources. Businesses can offer several sales and marketing tactics using different approaches like advertisements, discounts, or designing coupons to improve customer retention and increase sales[17]. The diversity in the preferences of modern customers, it is difficult for businesses to satisfy every customer. This challenge has been addressed using the customer segmentation technique, which enables businesses to divide customers into distinct and internally homogeneous groups and heterogeneous groups[18].

Table 1 . Shows the trends of customer techniques in years $(2015-2020)$.

\begin{tabular}{|c|c|c|c|c|}
\hline $\begin{array}{r}\text { Customer } \\
\text { Churn }\end{array}$ & $\begin{array}{l}\text { Customer } \\
\text { Satisfaction }\end{array}$ & $\begin{array}{l}\text { Customer } \\
\text { Visit/Revisit }\end{array}$ & $\begin{array}{c}\text { Customer } \\
\text { Demand/Purch } \\
\text { ase }\end{array}$ & $\begin{array}{c}\text { Customer } \\
\text { Segmentati } \\
\text { on }\end{array}$ \\
\hline $\begin{array}{l}\text { S. Yuan, } \\
\text { et al }\end{array}$ & $\begin{array}{c}\text { J. K. Von } \\
\text { et al }\end{array}$ & Q. Hu et al & $\begin{array}{l}\text { A. Martínez } \\
\text { et al }\end{array}$ & $\begin{array}{c}\text { Blessing } \\
\text { and } \\
\text { Natt } \\
\text { er }\end{array}$ \\
\hline $\begin{array}{l}\text { A. De } \\
\text { Caig } \\
\text { ny et } \\
\text { al }\end{array}$ & $\begin{array}{l}\text { A. } \\
\text { Alams } \\
\text { yah } e t \\
\text { al }\end{array}$ & S. Kim et al [23] & T. Van et al [24], & $\begin{array}{r}\text { X. Chen } \\
\text { et al }\end{array}$ \\
\hline \multirow[t]{5}{*}{$\begin{array}{r}\text { Dahiya, } \\
\text { et al }\end{array}$} & $\begin{array}{c}\text { Hendra } e t \\
\text { al }\end{array}$ & $\begin{array}{l}\text { Yarimoglu } \\
\text { and } \\
\text { Gunay }\end{array}$ & $\begin{array}{l}\text { Y. Nancy et } \\
\text { al }\end{array}$ & $\begin{array}{l}\text { M. T. } \\
\begin{array}{l}\text { Ball } \\
\text { estar } \\
\text { et al }\end{array}\end{array}$ \\
\hline & $\begin{array}{c}\text { S. Ding et } \\
\text { al }\end{array}$ & $\begin{array}{cc}\text { Alnsour } & {[10]} \\
\text { and } \mathrm{Al} & \\
\text { Faour } & \end{array}$ & R. Shi et al & $\begin{array}{l}\text { S. Peker } \\
\text { et al }\end{array}$ \\
\hline & $\begin{array}{l}\text { J. Herzig et } \\
\text { al }\end{array}$ & $\begin{array}{l}\text { A. Griva et } \\
\text { al }\end{array}$ & L. Wu et al & \\
\hline & & & C. Lee $e t$ al & \\
\hline & & & L. Tang et al [13] & \\
\hline
\end{tabular}


Vol. 2, No. 2, September 2020

\begin{tabular}{ccccc}
\hline p-ISSN: 2656-5935 & http://journal-isi.org/index.php/isi & e-ISSN: 2656-4882 \\
\hline \multicolumn{5}{c}{ Customer } \\
Churn & $\begin{array}{c}\text { Customer } \\
\text { Satisfaction }\end{array}$ & Visit/Revisit & $\begin{array}{c}\text { Customer } \\
\text { Demand/Purch } \\
\text { ase }\end{array}$ & $\begin{array}{c}\text { Customer } \\
\text { Segmentati } \\
\text { on }\end{array}$ \\
\hline & & Y. T. Wen & {$[35]$} \\
et al & & \\
\hline
\end{tabular}

The table above presents the main five techniques used by researchers to solve customer problems in the last five years.

\section{Techniques Distribution}

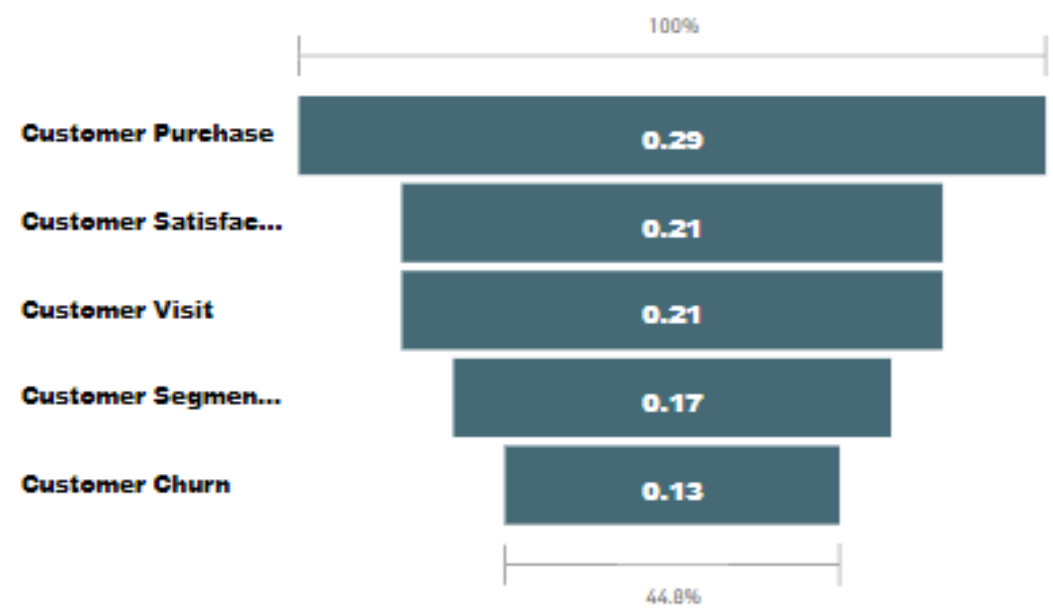

Fig 2. Shows the distribution of techniques used with customers.

The figure presents the five popular techniques used with the customer for the last five years. According to the figure above, customer purchase is the most popular technique used by the research community with about 29 percent. Followed by, customer satisfaction and visit with 21 percent. While customer churn is the least technique used.

\section{CUSTOMER PURCHASE TRENDS}

Table 2. shows the customer purchase technique trends in research.

\begin{tabular}{lllll}
\hline Statement & Year & Method & Data & Target \\
\hline Customer & 2016 & Bayesian & Radio & Predict \\
Purchase[36] & & Network & $\begin{array}{l}\text { Frequency } \\
\text { Data }\end{array}$ & $\begin{array}{l}\text { purchase } \\
\text { behavior }\end{array}$ \\
\hline Customer & 2017 & FA-based SVM & Clickstream & $\begin{array}{l}\text { Predict next } \\
\text { purchase }\end{array}$ \\
Purchase[13] & & & & Predict \\
\hline Customer & 2017 & logistic & Sales Data & \\
\hline
\end{tabular}


Vol. 2, No. 2, September 2020

\begin{tabular}{|c|c|c|c|c|}
\hline p-ISSN: 2656-5935 & \multicolumn{3}{|c|}{ http://journal-isi.org/index.php/isi } & e-ISSN: 2656-4882 \\
\hline Purchase[8] & & $\begin{array}{l}\text { regression, } \\
\text { decision trees, } \\
\text { SVM, neural } \\
\text { networks and } \\
\text { random forests }\end{array}$ & & $\begin{array}{l}\text { purchase } \\
\text { behavior }\end{array}$ \\
\hline $\begin{array}{l}\text { Customer } \\
\text { Purchase[37] }\end{array}$ & 2017 & $\begin{array}{l}\text { Structural } \\
\text { Equation } \\
\text { Model(SEM) }\end{array}$ & Sales Data & $\begin{array}{l}\text { Predict } \\
\text { purchase } \\
\text { intention }\end{array}$ \\
\hline $\begin{array}{l}\text { Customer } \\
\text { Purchase[38] }\end{array}$ & 2017 & $\begin{array}{l}\text { Structural } \\
\text { Equation } \\
\text { Model(SEM) }\end{array}$ & Survey & $\begin{array}{l}\text { Predict } \\
\text { purchase } \\
\text { intention }\end{array}$ \\
\hline $\begin{array}{l}\text { Customer } \\
\text { Purchase[1] }\end{array}$ & 2018 & $\begin{array}{l}\text { Gradient Tree } \\
\text { Boosting 89\% }\end{array}$ & Sales Data & $\begin{array}{l}\text { Predict } \\
\text { purchase } \\
\text { behavior }\end{array}$ \\
\hline $\begin{array}{l}\text { Customer } \\
\text { Purchase[15] }\end{array}$ & 2018 & Random Forest & $\begin{array}{l}\text { Insurance } \\
\text { Records }\end{array}$ & $\begin{array}{l}\text { Predict future } \\
\text { purchase }\end{array}$ \\
\hline $\begin{array}{l}\text { Customer } \\
\text { Purchase[39] }\end{array}$ & 2018 & $\begin{array}{l}\text { Multiple } \\
\text { Regression }\end{array}$ & $\begin{array}{l}\text { Purchase Data } \\
\text { (mobile users) }\end{array}$ & $\begin{array}{l}\text { Predict } \\
\text { purchase } \\
\text { behavior }\end{array}$ \\
\hline $\begin{array}{l}\text { Customer } \\
\text { Purchase[40] }\end{array}$ & 2019 & $\begin{array}{l}\text { Linear DID } \\
\text { Regression }\end{array}$ & Social Media & $\begin{array}{l}\text { Predict } \\
\text { purchase } \\
\text { behavior }\end{array}$ \\
\hline $\begin{array}{l}\text { Customer } \\
\text { Purchase[17] }\end{array}$ & 2020 & K-Means & Sales Data & $\begin{array}{l}\text { Predict } \\
\text { purchase } \\
\text { behavior }\end{array}$ \\
\hline
\end{tabular}

Table 2 shows the customer purchase technique and the popular algorithms and data used to address customer purchase prediction. According to the above table, most of the data used are sales records, meanwhile, social media, and big data were not commonly used

\section{FUTURE PRIORITIES FOR CUSTOMER ANALYTICS}

Customer analysis and prediction is a promising field as the amount of customer data is increasing vertically, and the expansion of data sources and platforms which generating different types of data related to customer transactions. 


\subsection{Social media}

Social media is used by billions of people around the world and has become one of the major methods of interaction with customers in recent years[41]. Businesses enhance their brand loyalty and customer engagement through their official account on social media. Worldwide, the total number of social media users is projected to grow to 3.29 billion users by 2022, which will be around $42.3 \%$ of the world's population. Facebook stated that having 2.38 billion monthly active users and 1.56 billion daily active users as of March 31, 2019. Given these huge possible users normally, spending long hours a day online on social media on different platforms. However, $85 \%$ of social media users consider that businesses should interact with consumers via social media websites[42]. Businesses are embracing social media as a marketing channel. It has become a significant data source and area of research[43]. One feature social media has is that it is changing very fast which could be observed quickly by businesses.

\subsection{Big Data}

Researchers accomplished a survey in the United States reported that $84 \%$ of leading firms have started big data analytics initiatives to get better accuracy in their decisions. Big data analytics deliver valuable insights to businesses to reduce expenses and maximize revenues. The practice proposes that a vital ingredient for success in using analytics efficiently is not only with the information technology, moreover includes a data-driven administrative culture[44]. The notion of customer participation in big data analytics is new and under research[45].

\section{RESULTS}

We surveyed the customer analytics literature for the last five years. From figure 2 customer purchase was the most popular technique used by the research community followed by customer satisfaction and visit. However, customer segmentation and customer churn were the last. From table 2 regression method was frequently used for predicting customer purchase and behavior. 


\section{CONCLUSION}

In this paper, we surveyed the literature of e-commerce to enable us to understand the current trends of customer techniques used in research. Big data and social media need more attention from researchers. Furthermore, identifying the current trends and future directions give us the advantage to redirect the research and use state-of-art techniques.

\section{FUTURE DIRECTIONS}

This work focused on the current trends which will turn give us future trends for research. More data is coming from social media; it is a rich source that may enable us to understand customer behavior more efficiently. Businesses need to develop methods for a personalized recommendation. Also, more work should be directed to analyze social media and big data to address customer issues

\section{REFERENCE}

[1] A. Martínez, C. Schmuck, S. Pereverzyev, C. Pirker, and M. Haltmeier, "A machine learning framework for customer purchase prediction in the noncontractual setting," Eur. J. Oper. Res., 2018, doi: 10.1016/j.ejor.2018.04.034.

[2] J. K. Von Bischhoffshausen, M. Paatsch, M. Reuter, G. Satzger, and H. Fromm, "An Information System for Sales Team Assignments Utilizing Predictive and Prescriptive Analytics," Proc. - 17th IEEE Conf. Bus. Informatics, CBI 2015, vol. 1, pp. 68-76, 2015, doi: 10.1109/CBI.2015.38.

[3] E. Yarimoglu and T. Gunay, "The extended theory of planned behavior in Turkish customers' intentions to visit green hotels," Bus. Strateg. Environ., vol. 29, no. 3, pp. 1097-1108, 2020, doi: 10.1002/bse.2419.

[4] M. T. Ballestar, P. Grau-Carles, and J. Sainz, "Customer segmentation in ecommerce: Applications to the cashback business model," J. Bus. Res., vol. 88, no. June, pp. 407-414, 2018, doi: 10.1016/j.jbusres.2017.11.047.

[5] S. Yuan, S. Bai, M. Song, and Z. Zhou, "Customer Churn Prediction in the Online New Media Platform: A Case Study on Juzi Entertainment," 2017 Int. Conf. Platf. Technol. Serv. PlatCon 2017 - Proc., pp. 0-4, 2017, doi: 10.1109/PlatCon.2017.7883698.

[6] S. Meinzer, U. Jensen, A. Thamm, J. Hornegger, and B. M. Eskofier, "Can machine learning techniques predict customer dissatisfaction? A feasibility study for the automotive industry," Artif. Intell. Res., vol. 6, no. 1, p. 80, 2016, doi: 10.5430/air.v6n1p80.

[7] J. Guo, X. Wang, and Y. Wu, "Positive emotion bias: Role of emotional 
content from online customer reviews in purchase decisions," J. Retail. Consum. Serv., vol. 52, no. October 2018, 2020, doi: 10.1016/j.jretconser.2019.101891.

[8] S. Peker, A. Kocyigit, and P. E. Eren, "A hybrid approach for predicting customers' individual purchase behavior," Kybermetes, vol. 46, no. 10, pp. 1614-1631, 2017, doi: 10.1108/K-05-2017-0164.

[9] J. Yeo, S. W. Hwang, S. Kim, E. Koh, and N. Lipka, "Conversion Prediction from Clickstream: Modeling Market Prediction and Customer Predictability," IEEE Trans. Knowl. Data Eng., vol. 32, no. 2, pp. 246-259, 2020, doi: 10.1109/TKDE.2018.2884467.

[10] M. Alnsour and H. R. Al Faour, "The influence of customers social media brand community engagement on restaurants visit intentions," Int. J. Cust. Relatsh. Mark. Manag., vol. 10, no. 4, pp. 1-14, 2019, doi: 10.4018/IJCRMM.2019100101.

[11] A. K. Bhowmick and B. Mitra, "Listen to me, my neighbors or my friend? Role of complementary modalities for predicting business popularity in location based social networks," Comput. Commun., vol. 135, no. June 2018, pp. 53-70, 2019, doi: 10.1016/j.comcom.2019.01.004.

[12] A. Ghahtarani, M. Sheikhmohammady, and M. Rostami, "The impact of social capital and social interaction on customers' purchase intention, considering knowledge sharing in social commerce context," J. Innov. Knowl., vol. 5, no. 3, pp. 191-199, 2020, doi: 10.1016/j.jik.2019.08.004.

[13] L. Tang, A. Wang, Z. Xu, and J. Li, "Online-purchasing behavior forecasting with a firefly algorithm-based SVM model considering shopping cart use," Eurasia J. Math. Sci. Technol. Educ., vol. 13, no. 12, pp. 7967-7983, 2017, doi: 10.12973/ejmste/77906.

[14] B. J. D. Jacobs, B. Donkers, and D. Fok, "Model-based purchase predictions for large assortments," Mark. Sci., vol. 35, no. 3, pp. 389-404, 2016, doi: $10.1287 / \mathrm{mksc} .2016 .0985$.

[15] S. Mau, I. Pletikosa, and J. Wagner, "Forecasting the next likely purchase events of insurance customers: A case study on the value of data-rich multichannel environments," Int. J. Bank Mark., vol. 36, no. 6, pp. 11251144, 2018, doi: 10.1108/IJBM-11-2016-0180.

[16] J. Feigl and M. Bogdan, "Neural networks for personalized item rankings," Neurocomputing, vol. 342, pp. 60-65, 2019, doi: 10.1016/j.neucom.2018.10.083.

[17] P. Anitha and M. M. Patil, "RFM model for customer purchase behavior using K-Means algorithm," J. King Saud Univ. - Comput. Inf. Sci., no. xxxx, 2020, doi: 10.1016/j.jksuci.2019.12.011.

[18] S. Peker, A. Kocyigit, and P. E. Eren, "LRFMP model for customer segmentation in the grocery retail industry: a case study," Mark. Intell. Plan., vol. 35, no. 4, pp. 544-559, 2017, doi: 10.1108/MIP-11-2016-0210.

[19] Q. Hu, S. Xie, J. Zhang, Q. Zhu, S. Guo, and P. S. Yu, "Hetero sales: 
Utilizing heterogeneous social networks to identify the next enterprise customer," 25th Int. World Wide Web Conf. WWW 2016, pp. 41-50, 2016, doi: $10.1145 / 2872427.2883000$.

[20] G. Blessing and M. Natter, "Do Mystery Shoppers Really Predict Customer Satisfaction and Sales Performance?," J. Retail., pp. 1-16, 2019, doi: 10.1016/j.jretai.2019.04.001.

[21] A. De Caigny, K. Coussement, and K. W. De Bock, "A new hybrid classification algorithm for customer churn prediction based on logistic regression and decision trees," Eur. J. Oper. Res., vol. 269, no. 2, pp. 760772, 2018, doi: 10.1016/j.ejor.2018.02.009.

[22] A. Alamsyah and F. Saviera, "A Comparison of Indonesia's E-Commerce Sentiment Analysis for Marketing Intelligence Effort (case study of Bukalapak, Tokopedia and Elevenia)," 8 th Int. Conf. Sustain. Collab. Bus. , Tecbnol. Inf. Innov., 2017.

[23] S. Kim and J. G. Lee, "A systematic framework of predicting customer revisit with in-store sensors," Knowl. Inf. Syst., 2019, doi: 10.1007/s10115019-01373-y.

[24] T. Van Nguyen, L. Zhou, A. Y. L. Chong, B. Li, and X. Pu, "Predicting customer demand for remanufactured products: A data-mining approach," Eur. J. Oper. Res., 2019, doi: 10.1016/j.ejor.2019.08.015.

[25] X. Chen, Y. Fang, M. Yang, F. Nie, Z. Zhao, and J. Z. Huang, "PurTreeClust: A clustering algorithm for customer segmentation from massive customer transaction data," IEEE Trans. Knowl. Data Eng., vol. 30, no. 3, pp. 559-572, 2018, doi: 10.1109/TKDE.2017.2763620.

[26] K. Dahiya and S. Bhatia, "Customer churn analysis in telecom industry," 2015 4th Int. Conf. Reliab. Infocom Technol. Optim. Trends Futur. Dir. ICRITO 2015, pp. 1-6, 2015, doi: 10.1109/ICRITO.2015.7359318.

[27] Hendra, E. S. Rini, P. Ginting, and B. K. F. Sembiring, "Impact of eCommerce service quality, recovery service quality, and satisfaction in Indonesia," Proc. - 2017 Int. Conf. Sustain. Inf. Eng. Technol. SIET 2017, vol. 2018-Janua, pp. 35-40, 2018, doi: 10.1109/SIET.2017.8304105.

[28] Y. (Nancy) Dai, G. Viken, E. Joo, and G. Bente, "Risk assessment in ecommerce: How sellers' photos, reputation scores, and the stake of a transaction influence buyers' purchase behavior and information processing," Comput. Human Behav., vol. 84, pp. 342-351, 2018, doi: 10.1016/j.chb.2018.02.038.

[29] S. Ding, Z. Wang, D. Wu, and D. L. Olson, "Utilizing customer satisfaction in ranking prediction for personalized cloud service selection," Decis. Support Syst., vol. 93, pp. 1-10, 2017, doi: 10.1016/j.dss.2016.09.001.

[30] R. Shi, H. Chen, and S. P. Sethi, "A generalized count model on customers' purchases in O2O market," Int. J. Prod. Econ., vol. 215, pp. 121-130, 2019, doi: 10.1016/j.ijpe.2017.11.009.

[31] J. Herzig, G. Feigenblat, M. Shmueli-Scheuer, D. Konopnicki, and A. 
Rafaeli, "Predicting customer satisfaction in customer support conversations in social media using affective features," UMAP 2016 - Proc. 2016 Conf. User Model. Adapt. Pers., pp. 115-119, 2016, doi: 10.1145/2930238.2930285.

[32] A. Griva, K. Pramatari, and C. Bardaki, "Customer Visit Segmentation Using Market Basket Data Using Market Basket Data," Proc. 2016 Pre-ICIS SIGDS A/IFIP WG8.3 Symp. Innov. Data Anal. Spec., pp. 6-9, 2016.

[33] L. Wu et al., "Product Adoption Rate Prediction in a Competitive Market," IEEE Trans. Knowl. Data Eng., vol. 30, no. 2, pp. 325-338, 2018, doi: 10.1109/TKDE.2017.2763944.

[34] C. Lee, X. Xu, and C. C. Lin, "Using online user-generated reviews to predict offline box-office sales and online DVD store sales in the $\mathrm{O} 2 \mathrm{O}$ era," J. Theor. Appl. Electron. Commer. Res., vol. 14, no. 1, pp. 68-83, 2019, doi: 10.4067/S0718-18762019000100106.

[35] Y. T. Wen, P. W. Yeh, T. H. Tsai, W. C. Peng, and H. H. Shuai, "Customer purchase behavior prediction from payment datasets," WSDM 2018 - Proc. 11th ACM Int. Conf. Web Search Data Min., vol. 2018-Febua, pp. 628-636, 2018, doi: 10.1145/3159652.3159707.

[36] Y. Zuo, "Prediction of consumer purchase behaviour using Bayesian network: an operational improvement and new results based on RFID data," Int. J. Knowl. Eng. Soft Data Paradig., vol. 5, no. 2, p. 85, 2016, doi: 10.1504/ijkesdp.2016.075976.

[37] S. P. Jeng, "Increasing customer purchase intention through product return policies: The pivotal impacts of retailer brand familiarity and product categories," J. Retail. Consum. Serv., vol. 39, no. January, pp. 182-189, 2017, doi: 10.1016/j.jretconser.2017.08.013.

[38] Y. Lou, W. Wang, and X. Yang, "Customers' Attitude on New Energy Vehicles' Policies and Policy Impact on Customers' Purchase Intention," Energy Procedia, vol. 105, pp. 2187-2193, 2017, doi: 10.1016/j.egypro.2017.03.617

[39] S. Jang, P. J. Kitchen, and J. Kim, "The effects of gamified customer benefits and characteristics on behavioral engagement and purchase: Evidence from mobile exercise application uses," J. Bus. Res., vol. 92, no. July, pp. 250-259, 2018, doi: 10.1016/j.jbusres.2018.07.056.

[40] Z. Yang, Y. Zheng, Y. Zhang, Y. Jiang, H. T. Chao, and S. C. Doong, "Bipolar influence of firm-generated content on customers' offline purchasing behavior: A field experiment in China," Electron. Commer. Res. Appl., vol. 35, no. February 2018, p. 100844, 2019, doi: 10.1016/j.elerap.2019.100844.

[41] A. Borah, S. Banerjee, Y. Lin, A. Jain, and A. B. Eisingerich, "Improvised Marketing Interventions in Social Media," 2020, doi: 10.1177/0022242919899383.

[42] E. T. Javid, M. Nazari, and M. R. Ghaeli, "Social media and e-commerce: A 
scientometrics analysis," Int. J. Data Netw. Sci., vol. 3, no. 3, pp. 269-290, 2019, doi: 10.5267/j.ijdns.2019.2.001.

[43] G. Appel, L. Grewal, R. Hadi, A. T. Stephen, A. T. Stephen, and G. Appel, "The future of social media in marketing," J. Acad. Mark. Sci., 2019, doi: 10.1007/s11747-019-00695-1.

[44] H. Hallikainen, E. Savimäki, and T. Laukkanen, "Fostering B2B sales with customer big data analytics," Ind. Mark. Manag., vol. 86, no. October 2019, pp. 90-98, 2020, doi: 10.1016/j.indmarman.2019.12.005.

[45] H. Zhang and Y. Xiao, "Customer involvement in big data analytics and its impact on B2B innovation," Ind. Mark. Manag., vol. 86, no. July 2018, pp. 99-108, 2020, doi: 10.1016/j.indmarman.2019.02.020. 